\title{
THE SYMBOL OF LIGHT'S RAY IN IMAGES OF THE ANNUNCIATION OF THE 14TH AND 15TH CENTURIES ACCORDING TO GREEK PATROLOGY
}

\author{
O SímBOLO dOS RAIOS DE LUZ NAS IMAGENS DA ANUNCIAÇÃO dOS SÉCULOS XIV E XV DE ACORDO COM A \\ PATROLOGIA GREGA
}

José María Salvador-González*
jmsalvad@ucm.es

ABSTRACT: The current article tries to interpret the deep doctrinal meanings derived from the visual and textual metaphors related to the ray of light, the Sun, and other light elements underlying the symbol of the beam of light depicted in the images of the Annunciation of the fourteenth and fifteenth centuries. To undertake this goal, we will follow two methodological strategies based on comparative analysis. Firstly, we will analyze some texts through which many Greek-Eastern Church Fathers interpret several biblical terms, such as Sol iustitiae, lux mundi, and other similar expressions as metaphors that symbolize God the Son incarnate. Secondly, we will analyze eight images of the Annunciation from the 14th and 15th centuries that include a ray of light emitted by God the Father towards the Virgin Mary. From the comparative analyzes between both sets, texts and images, we will conclude that this ray of light represented in such Annunciations is a visual metaphor that illustrates the textual metaphors deciphered by the Greek-Eastern Fathers from the Biblical expressions mentioned, as a symbol of Christ, "Sun of Justice" and" light of the world", which is incarnated to redeem Humanity from the darkness of error and sin.

KEYWORDS: Christ's Incarnation, Annunciation, Divine motherhood, Ray of light, Greek Patrology, Christian iconography.

RESUMO: Este artigo tenta interpretar os significados doutrinais profundos derivados de metáforas textuais e visuais relacionadas ao raio de luz, ao Sol e outros elementos de luz subjacente ao símbolo do raio de luz pintado nas imagens da Anunciação dos séculos XIV e XV. Para isso, seguiremos duas estratégias metodológicas baseadas em análise comparativa. Em primeiro lugar, analisaremos alguns textos através dos quais numerosos Padres da Igreja Grego-Oriental interpretam vários termos bíblicos, como Sol iustitiae, lux mundi e outras expressões semelhantes como metáforas que simbolizam Deus, o Filho encarnado. Em segundo lugar, analisaremos oito imagens da Anunciação dos séculos XIV e XV que incluem um raio de luz emitido por Deus Pai em direção à Virgem Maria. A partir das análises comparativas entre conjuntos, textos e imagens, concluiremos que esse raio de luz representado em tais Anunciações é uma metáfora visual que ilustra as metáforas textuais decifradas pelos Padres Greco-Orientais nas expressões bíblicas mencionadas, como um símbolo de Cristo, "Sol da Justiça"e "luz do mundo", encarnada para resgatar a Humanidade das trevas do erro e do pecado.

PAlAVRAS-CHAVE: Encarnação de Cristo, Anunciação, Maternidade divina de Maria, Raio de luz, Patrologia Grega, Iconografia cristã.

\footnotetext{
* PhD in Aesthetics and Art Sciences at the Panthéon-Sorbonne University, Paris I (1981), PhD in Social Sciences at the Central University of Caracas, Venezuela (2002), PhD in Art History at the Complutense University of Madrid (2007), and PhD in Sciences of Religion at Complutense University of Madrid (2018). Post-Doctorat in Aesthetics and Iconography of the Middle Ages at the Central University of Caracas, Venezuela (2010). He is Professor of Art History at the Complutense University of Madrid, where he is the founder and Director of the academic journal De Medio Aevo https://revistas.ucm.es/index.php/DMAE.
} 


\section{Introduction}

In the increasingly complex and realistic images of the Annunciation in the 14th and 15th centuries, a beam of light appears generally included, as an almost essential element, which, emanating from God the Father and almost always carrying the Holy Spirit shaped like a dove, descends on the Virgin Mary. Now, although most art historians and iconographers, such as Louis Bréhier (1928), Émile Mâle (1995), Manuel Trens (1947), Louis Réau (1957), Giuseppe M. Toscano (1960), André Grabar (1979), or Gertrud Schiller (1971; 1980), mention this beam of light as a compositional or narrative detail of the scene, almost none of them offers a documentary justified iconographic interpretation of its possible doctrinal meanings.

In this sense, taking into account that, at the same moment in which the episode of the Annunciation ends with the unconditional acceptance of Mary to the divine plan announced by the angel, the incarnation of the Son of God in Mary's womb becomes effective, It is logical to suppose that this ray of light represented in the artistic images of the Annunciation has some symbolic scope essentially linked with God the Son incarnate as a man. In this article, we propose to provide a plausible answer to such a conjecture, based on documentary arguments drawn from the patristic and theological tradition.

To undertake this goal, we will follow two complementary methodological strategies based on comparative analysis. Firstly, we will analyze some texts through which many GreekEastern Church Fathers interpret several biblical terms, such as Sol iustitiae, lux mundi, and other similar expressions as metaphors that symbolize God the Son incarnate. Secondly, we will analyze eight images of the Annunciation from the 14th and 15th centuries that include a ray of light emitted by God the Father towards the Virgin Mary. From the comparative analyzes between both sets, texts, and images, we will conclude that this ray of light represented in such Annunciations is a visual metaphor that illustrates the symbol of Christ, "Sun of Justice" and" light of the world", incarnated to redeem Humanity from the darkness of error and sin, following the interpretations of some Greek-Eastern Father when deciphering the Biblical textual metaphors mentioned above.

The exegetical tradition of some Greek-Eastern Church Fathers on the Christological metaphors lux mundi, Sol iustitiae and other expressions alluding to luminosity

Since at least the 3rd century, many Fathers and theologians of the Latin and Greek- 
Eastern Churches designate Christ as "Sun", "Orient", "light", "flame", "illumination", and other metaphorical terms alluding to gleaming phenomena. In this order of ideas, we will analyze below a select series of exegetical quotations using which some prestigious GreekEastern Church Fathers decipher those poetic metaphors according to an explicit Christological projection. In this regard, it is worth specifying at the outset that, to facilitate their transcription, the textual quotations that we present from these Greek-Eastern authors in this article are extracted from the Latin translation that Jacques-Paul Migne gives of them in his Patrología Graeca. ${ }^{1}$ Thus the paraphrases and the textual translations into English that we have made in this article are based on the Latin translation brought by Migne.

In the first quarter of the 4th century Eusebius of Caesarea ( + c. 339), when he glossed in one of his writings the biblical sentence "he put his tabernacle in the sun", says that the Sun bowed before the divinity, in which God the Son put his seat as his tabernacle, or, in other words, that he took from the Virgin Mary a human body, which was like the tabernacle of the divine power that remained in him (EUSEBIUS CAESARIENSIS, Eclogae propheticae. Liber II, 10. PG 22, 1105). ${ }^{2}$ Thus, although in a rather vague and ambiguous way, Eusebius of Caesarea is, to our knowledge, the first Greek Father to relate the Sun to God the Son by incarnating as a man in Virgin Mary's womb.

Towards the middle of the 4th century, the poet and hymnographer St. Ephrem of Syria (307-373), in one of his lyrical hymns, exploits, again and again, the suggestive metaphors of light by praising the incarnation and the birth of Christ, whom he continually identifies with the divine Sun. It begins, in effect, by saying that "When [God] the Son was born, the light rose, and the darkness fled from the world and the orb of the Earth shone, to praise the splendor of God the Father [Christ], that lit it up" (EPHREMUS SYRUS, Carmina Sogita 4, In: ALVAREZ CAMPOS, 1970, v. II, p. 499). ${ }^{3}$ Ephrem then goes on to say that the Sun / Christ "rose from the body of the Virgin Mary, the shadows disappeared, because He came. And the

\footnotetext{
${ }^{1}$ To facilitate the writing of the Greek-Eastern Fathers in our alphabet, we will quote the texts of these authors in the footnotes of the current paper according to the Latin translation given by Jacques-Paul MIGNE in his Patrologiae Cursus Completus, Series Graeca, Paris, Garnier Frères, 1857-1867, 166 vols. This collection of Greek Patrology is identified with the abbreviation PG.

2 "'in sole posuit tabernaculum suum;' sol deitatem innuit, in qua sedem suam et quasi tabernaculum posuit, vel quod ex Virgine sumpsit corpus, quod quasi tabernaculum erat divinae potestatis in eo permanentis." (EUSEBIUS CAESARIENSIS, Eclogae propheticae. Liber II, 10. PG 22, 1105).

3 "In nativitate Filii surrexit lux, et fugerunt e mundo tenebrae et orbis terrae emicuit; ut laudet Patris Splendorem, qui eam illuminavit." (EPHremus Syrus, Carmina Sogita 4, In: Alvarez Campos, 1970, v. II, p. 499).
} 
darkness and error are expelled by Him, and the ends of the Earth shone to praise Him" (EPHREMUS SYRUS, Carmina Sogita 4, In: ALVAREZ CAMPOS, 1970, v. II, p. 499). ${ }^{4}$ As if that wasn't enough, the Syrian hymnographer expresses that "There was a great tumult among the peoples, since the light arose amid the darkness. And they exulted to celebrate Him by whom all are enlightened" (EPHREMUS SYRUS, Carmina Sogita 4, In: ALVAREZ CAMPOS, 1970, v. II, p. 499). ${ }^{5}$ Finally, Ephrem concludes stating that "The Star [Christ] rushing emerged from the darkness, and invited those who came with Him to enjoy the great light that had come down to Earth" (EPHREMUS SYRUS, Carmina Sogita 4, In: ALVAREZ CAMPOS, 1970, v. II, p. 499). ${ }^{6}$ As seen by these reiterated versified concepts, St. Ephrem is one of the Fathers who, with greater poetic force and with more magnificent obsession, identify Christ with the Sun, the light and the luminous star that dispels the darkness.

About seven decades later St. Cyril of Alexandria (c.370 / 73-444) in a sermon in honor of the Virgin Mary praises her as "the most precious being in the entire world", "the incorrupt dove", "the inextinguishable lamp", "because from you the Sun of justice [Christ] has been born", "the place of the one who does not fit anywhere, the one who gave birth to the Word Only Begotten, the one who germinated the unfading spike [Christ] without plowing or seed" CYRILLUS ALEXANDRINUS, Homilia XI. Encomium in sanctam Mariam Deparam. PG 77, 1.031). ${ }^{7}$ A few paragraphs later, Cyril goes on to exalt the Virgin with these poetic terms:

Hail, Mary Mother of God, through whom the right light was born, our Lord Jesus Christ, who says in the Gospels: "I am the light of the world." Hail, Mary Mother of God, through whom the light shone to those who sat in darkness and the shadow of death. "Because the people," he says, "who were sitting in the darkness, saw a great light. And what truth is that light, if not our Lord Jesus Christ, that true light that illuminates every man who comes into this world?" (CYRILLUS ALEXANDRINUS, Homilia XI. Encomium in sanctam Mariam Deparam. PG 77, 1.034) ${ }^{8}$

\footnotetext{
4 "Surrexit ex corpore Virginis: umbrae disparuerunt, quia ipse advenit. Et tenebrae ab eo pulsae sunt et error, emicueruntque terrarum fines ut eum laudent.".

5 "Inter populos coortus est magnus tumultus; in tenebris enim surrexit lux. Et exsultarunt populi ut eum celebrent per cuius nativitatem omnes illuminati sunt."

6 "Festinum currens sidus inter tenebras surrexit, eosque invitavit ut secum venientes magno lumine quod in terras descenderat fruerentur."

7 "Salve, Maria, pretiosissima res totius Orbis; salve, Maria, columba incorrupta; salve, Maria, lampas inexstinguibilis : ex te enim natus est Sol justitiae, Salve Maria locus ejus qui loco non capitur, quae unigenitun Deum Verbum cepisti, quae spicam sine aratro et semine germinasti immarcescibilem."

8 "Salve, Maria Deipara, per quam prodiit lux vera, Dominus noster Jesus Christus, qui dicit in Evangeliis: "Ego sum lux mundi». Salve. Maria Deipara, per quam illuxit lumen sedentibus in tenebris, et umbra mortis. «Populus enim, inquit, qui sedebat in tenebris, vidit lucem magnam. Ecquam vero lucem, nisi Dominum nostrum Jesum Christum, lucem illam veram quae illuminat omnem hominem venientem in hunc mundum?"
} 
Furthermore, in a treatise against Nestorius, St. Cyril of Alexandria points out that "that Word who was God, and that Son who was wisdom, life, and light, is called Jesus Christ, and the Son who was Wisdom" (CYRILLUS ALEXANDRINUS, Adversus Nestorii blasphemias. Liber Primus, VII. PG 76, 47).9

More or less for the same years St. Proclus of Constantinople (ante 390-c. 446/48) in a sermon on the incarnation of Christ, interpreting the testimony of the Biblical prophet who claimed to be seeing an utterly golden candelabrum, affirms that the Virgin Mary is that golden candelabrum because she conceived the Son of God incarnate. Proclus goes on to point out that, just as the candelabrum is not the cause of the flame, but only its support, so also the Virgin Mary is not herself God, but the temple of God. ${ }^{10}$ Interpreting the following phrase of the prophet "And the flame was on it [candelabrum]", Proclus states that this flame

is the Word of God incarnate, the light of the terrestrial orb, the one that says: I am the light of the world. For just as in the flare matter receives the flame, so in the incarnation, God took the form of a slave. And just as the blaze emits radiance from above, so God came to Earth from heaven (PROCLUS CONSTANTINOPOLITANUS, Oratio II. De incarnatione Domini nostri Jesu Christi, et de infusoriis. PG 65, 699 (PG 65, 691-704). ${ }^{11}$

In another speech on the Nativity of Jesus St. Proclus, after stating that the only Son of God cannot be born of two parents, he affirms that today (Christmas day) the Sun of justice, Christ, was born from a virginal cloud (Mary) and the people who were sitting in the darkness saw the great light. ${ }^{12}$ In another writing in honor of the Virgin, Proclus asserts that Mary is the globe of the new celestial creature, in which the Sun of justice, which never dies, chased the sins away from all souls all night. ${ }^{13}$

\footnotetext{
9 "Tunc enim illud Verbum quod Deus erat, et ille Filius qui erat sapientia, et vita et lux, appellatus est Jesus Christus. Perspicuum est igitur, illam ex sancta Virgine nativitatem eodem tempore cum ejusmodi appellatione concurrisse".

10 "Et sicut candelabrum non est lucis causa, sed lucis vehiculum : ita etiam virgo non est ipsa Deus, sed Dei templum. Et lampas, inquit, super ipsum." (Proclus ConstantinOPolitanus, Oratio II. De incarnatione Domini nostri Jesu Christi, et de infusoriis. PG 65, 699 (PG 65, 691-704).

11 "Quidnam est lampas? Deus Verbum incarnatum. Lumen orbis terrae, is qui dicit: Ego sum lux mundi. Sicut autem in lampade materia flammam excipit, ita in mysterio ac incarnatione Deus servi formam suscepit. Et quemadmodum lampas splendorem ex alto demittit, ita Dominus e coelis in terram venit."

12 "Unus quippe Filius, duplici patre nasci non potest. Ego hodie genui te. Hodie namque justitiae sol e virginea nube ortus est. Populus enim qui sedebat in tenebris vidit lucem magnam." (Proclus ConSTANTINOPOLITANUS, Oratio IV. In natalem diem Domini nostri lesu Christi, III. PG 65, 714).

13 "Ipsa, novae creaturae coelestis globus, in qua Sol justitiae nunquam occidens, omnem ab anima omni peccatorum noctem fugavit." (Proclus Constantinopolitanus, Oratio VI. Laudatio sanctae Dei genitricis Mariae. PG 65, 754-758 (722-758).
} 
More or less for the same years, Hesychius of Jerusalem ( + c. 450 ), in a sermon in honor of the Virgin Mary begins by resuming some Mariological interpretations already spread by the Church Fathers on Ezekiel's porta clausa: in such sense, he assures that some call Mary "the closed door [of the temple] located towards the East", who introduced the world to the king of closed doors (Christ), and also some called her "the door that emits or causes to go out" (the Sun of the East), for having become the exit door for the Only Begotten of present life (the Son of God incarnate) ${ }^{14}$ Hesychius goes on to express that the Virgin became the closed door to the East, because Christ, who is the pure light that illuminates every man who comes into this world, ${ }^{15}$ comes out of the womb of Mary as the husband comes out of his royal bridal chamber. ${ }^{16}$

Perhaps around the same time that Hesychius of Jerusalem expressed these terms, the renowned poet Jacob of Serugh ( + c. 460), famous for his Syriac-versed homilies, exploits in many of them the rich possibilities of those poetic metaphors, alluding to light, Sun and light source. ${ }^{17}$ Thus in one of his sermons in verse in honor of the Virgin Mary he proclaims:

From her [Mary], the Sun of justice, and the beautiful light [Christ] that expelled the darkness of the world was born.

God the Father wanted her to be the mother of his Only Begotten Son:

Therefore the happiness of all people is excellent.

(IACOBUS SARUGENSIS, Homilia de beata Virgine Matre Dei Maria. In: ALVAREZ CAMPOS, 1981, vol. V, p. 22). ${ }^{18}$

In another Marian sermon, the poet of Serugh abounds in expressions of a similar astral and light nature when he points out:

[Mary] was decent and splendid among the women,

Because she gave birth to the Sun, which did not corrupt or stain the decorum of her virginity.

\footnotetext{
14 "alius te appellavit portam clausam in oriente sitam, quae introduxit clausarum portarum regem: necnon etiam portam emittentem te vocavit, quoniam porta praesentis vitae Unigenito effecta es." (HesYCHIUS Hierosolymitanus, Sermo V. De sancta Maria Deipara Homilia. PG 93, 1459-1463).

${ }^{15}$ Hesiquio funda aquí su argumentación en el texto del Evangelio de San Juan, que dice de Jesús: "erat lux vera quae inluminat omnem hominem venientem in mundum". (Jn 1,9).

16 "Portam in oriente sitam, quia lux vera, quae illuminat omnem hominem venientem in mundum, ex utero tuo processit, velut e quodam thalamo regio." (Ibid.).

${ }_{17}$ Due to the difficulty that the ignorance of the original Syriac language entails for us, we will use the Latin translation of the texts of Jacob de Sarug offered by Sergio Álvarez CAMPOS in his Corpus Marianum Patristicum, vol. V, Burgos, Aldecoa, 1981.

18 "Ab ipsa [María] magnus iustitiae Sol exortus est, atque lux splendida [Cristo] quae tenebras e regione depellit. Ipsam Pater voluit esse Unigeniti sui matrem; unde magna est pro omnibus natis felicitas."
} 
Or if she were not a virgin, wanting the Son of the Creator to live in her, It was convenient for him to preserve her virginity when he left [at birth]. (IACOBUS SARUGENSIS, Homilia de sancta Dei Matre et perpetua Virgine. In: ALVAREZ CAMPOS, 1981 , vol. V, p. 52). ${ }^{19}$

In another stanza of that same versified sermon, Jacob of Serugh rounds out a similar idea by saying:

[Mary] Was a chaste Virgin when the Father's ray of light dwelt in her, And she was a virgin when the child grew in her womb.

Being a virgin, she gestated [carried] the Strong One who gives the world, And was a virgin engendering the Father's Virtue.

(IACOBUS SARUGENSIS, Homilia de sancta Dei Matre et perpetua Virgine. In: ALVAREZ CAMPOS, vol. V, p. 59-60). ${ }^{20}$

In the following 6th century, the famous hymnographer Romanus the Melodist affirms in his Hymn 16 that "Christ shines like a great light; a bright light appeared in Bethlehem to those who are in darkness; but rather the Lord emitted to all the earth the rays of the Sun of justice coming from Mary" (ROMANUS CANTOR, Hymnus 16, 1. In: ALVAREZ CAMPOS, 1979, p. 132). ${ }^{21}$

In that same 6th century, an anonymous hymnographer took up the metaphors of the Sun, light, and rays in his way. In this sense, he points out in Hymn 2: "In Mary all virgins boast, because the Virgin Mary is the cause of goods. The light for those who sat in darkness came out of her" (ANONYMUS HIMNOGRAPHUS, c. 6th century, Hymnus 2, In: ALVAREZ CAMPOS, 1981, p. 159). A few stanzas later he goes on: "For Mary the light was born, which dispelled the darkness brought by Eve and spread over all the human race. Through Mary the world locked in darkness was illuminated" (ANONYMUS HIMNOGRAPHUS, c. 6th century, Hymnus 2, In: ALVAREZ CAMPOS, 1981, p. 159).

In his Hymn 8 this anonymous author, after pointing out that the Virgin Mary is blessed to become the Mother of the Creator of all, assures that she is praised for having been

\footnotetext{
19 "[Mary] Decora fuit valde, in feminis splendida, quia peperit Solem; qui non corrupit neque turpavit virginitatis decus. Vel si non esset virgo, volens Filius Creatoris in ea habitare, expediebat ut virginem desereret cum exivit."

20 "Virgo fuit pura quando in ea habitavit Patris radius, et virgo quando crescebat in alvo sua parvulus.

Virgo portavit Fortem qui mundum portat, virgoque fuit generans Patris Virtutem."

21 "lux magna splendet Christus: iis qui in tenebris erant fulgidum apparuit lumen a Bethleem coruscans; sed potius ex Maria Dominus omnibus terris emittit radios sol iustitiae."
} 
converted for the world into a source that emanates all goods and because the light of the world was born of her (ANONYMUS HIMNOGRAPHUS, c. 6th century, Hymnus 8, In: ALVAREZ CAMPOS, 1981, p. 164-165). And in Hymn 9 the anonymous poet exclaims: "Blessed are you, oh blessed, because through you the curse of Eve was absolved and suppressed in women. [...]. For you gave birth to the treasure that lavished all aid on the world. the light with which the darkness and all its powers were dissipated, so that they no longer exist, was born of you" (ANONYMUS HIMNOGRAPHUS, c. 6th century, Hymnus 9, In: ALVAREZ CAMPOS, 1981, p. 165166). ${ }^{22}$

In the first half of the 8th century, the influential polygraph St. John Damascene (676749), in a sermon on the birth of Mary, ensures that today (when the Virgin is born) God founded heaven on Earth with an earthly nature, and this heaven is even more supernatural and more beautiful, because the one who (God the Son) founded the Sun in him, will be born of her (Mary) as the Sun of justice. ${ }^{23}$

Already in the 9th century, the prestigious Greek poet St. Joseph the Hymnographer $(+883)$ in one of his many songs in honor of Mary emphasizes the idea that "The prophet, oh Mother of God, once called you an intellectual candelabrum, bearer of the divine lamp, which illuminated those who were previously clouded by the many darknesses of evil. You have been made the abode of light" (JOSEPHUS HYMNOGRAPHUS, Mariale. Theotocia seu Deiparae Strophae. PG 105, 1.051 (1.041-1.279). ${ }^{24}$ Several paragraphs later, he continues proclaiming: "The light born from your uterus illuminated the orb of the earth, O Virgin, and Jesus, the one who gives light, deeply eliminated everywhere the fog of demons and the darkness of ignorance" (JOSEPHUS HYMNOGRAPHUS, Mariale. Theotocia seu Deiparae Strophae. PG 105, 1.055 (1041-1279). ${ }^{25}$ In another subsequent passage from that same hymnbook Joseph, the Hymnographer states: "The Sun of justice, born in an ineffable way from you, $\mathrm{O}$ dearest

\footnotetext{
22 "Beata es, o benedicta; quia per te soluta et a feminis ablata est maledictio Hevae [...]. Tu enim peperisti thesaurum qui omnia auxilia mundo largitus est. In te orta est lux qua tenebrae earumque potestas dissipatae fuere, ita ut amplius non sint."

23 "Hodie in terra ex terrena natura coelum ille condidit, qui olim ex aquis firmamentum compegerat, et in altum extulerat. Ac sane coelum istud illo longe divinius est, ac stupendum magis. Nam qui solem in illo condidit, ex hoc ipse justitiae sol oriturus est." (IOANNES DAMASCENUS, Homilia in Nativitatem B.V. Mariae. PG 96, 663 (661679).

24 "Intellectuale candelabrum te olim, Dei genitrix, propheta designavit, ferens lampadem divinam, quae illuminavit eos, qui plurimis malorum tenebris prius erant obfusi. Lucis habitaculum facta es".

25 "Lux ex utero tuo exorta terrarum orbem illuminavit, o Virgo, ac daemonum nebulam, atque ignorantiae tenebras undequaque penitus eliminavit, Jesus lucis dator."
} 
Maiden to God, illuminated the entire terrestrial orb and dissipated the storm of error" (JOSEPHUS HYMNOGRAPHUS, Mariale. Theotocia seu Deiparae Strophae. PG 105, 1.102 (1041-1279). ${ }^{26} \mathrm{~A}$ couple of pages later, he continues: "Your uterus has been converted into the abode of light, which illuminated the world with the splendors of divinity: the gate of the sun of glory, most gracious among all women, the glory of the saints, holiest and optimal" (JOSEPHUS HYMNOGRAPHUS, Mariale. Theotocia seu Deiparae Strophae. PG 105, 1.106 (1041-1279). ${ }^{27}$ In another passage of that same hymn repertoire, Joseph the Hymnographer assures that the prophet Ezekiel saw Mary as the closed door of the temple through which the Sun of justice, Christ, who plucked the man from corruption (JOSEPHUS HYMNOGRAPHUS, Mariale. Theotocia seu Deiparae Strophae. PG 105, 1.163-1.164); ${ }^{28}$ then the hymnographer specifies that the prophets from the Old Testament designated the Virgin Mary with the suggestive metaphors "gate, and mount, and holy tabernacle: the cloud of light, of which the Sun was born, the only giver of light [Jesus] for those who sit in the darkness and shadow" (JOSEPHUS HYMNOGRAPHUS, Mariale. Theotocia seu Deiparae Strophae. PG 105, 1.163$1.164) \cdot{ }^{29}$

In another subsequent passage from another Marian hymn, he calls the Virgin "the purest", "shining gate" (revealed to Ezekiel), that "gave birth in an ineffable way to the giver of the light, made like us" (JOSEPHUS HYMNOGRAPHUS, Theotocia Ex Paracletica Graecorum. PG 105, 1.379)..$^{30}$ Finally, in another of his many Marian poems, Joseph the Hymnographer praises the Virgin Mother of God, calling her "the Spiritual Door of Light", through which Christ, appearing with all the beauty and splendor of godhead, entered with us hidden under the stole of the flesh, invisible as God, but visible in our human form (JOSEPHUS HYMNOGRAPHUS, Mariale. Theotocia Sive Allocutiones ad beatam Virginem Deiparam. PG $105,1.411) .{ }^{31}$ Thus, this Greek-Byzantine poet stands among the large group of Church Fathers

\footnotetext{
26 "Ex te, o Puella Deo charissima, justitiae Sol ineffabili ratione exortus, universum terrarum orbem illuminavit, et erroris tempestatem dissipavit."

27 "Lucis habitaculum uterus factus est, quae mundum divinitatis splendoribus illuminavit: porta solis gloriae, gratiosissima inter mulieres, sanctorum gloriatio, sanctissima atque optima."

28 "Portam te vidit Ezechiel, o Deipara, per quam transivit Sol gloriae, qui hominem a corruptione eripuit: quem deprecare pro redemptione servorum tuorum."

29 "Sacrae prophetarum voces te praedicant symbolice, o Virgo, portam, et montem, et tabernaculum sanctum: lucis nubem, ex qua sedentibus in tenebris et umbra exortus est sol, unicus lucis dator."

30 "Te lucis portam fulgidam vidit Propheta, o purissima: lucis enim datorem nobis similem factum ineffabili ratione peperisti, quem superexaltamus in universa saecula."

31 "Portam spiritualem Lucis te, Dei Mater, nominamus, per quam ingressus est ad nos Christus speciosus apparens splendoribus divinitatis, occultatus in stola carnis, invisibilis ut Deus, in forma autem nostra visibilis."
} 
who describe the Son of God incarnate as the "Sun of justice" who passes through "the closed eastern door of the temple", which is the Virgin Mary.

Iconographic analysis of some images of the Annunciation of the XIV and XV centuries from the perspective of the Greek-Eastern Patrology

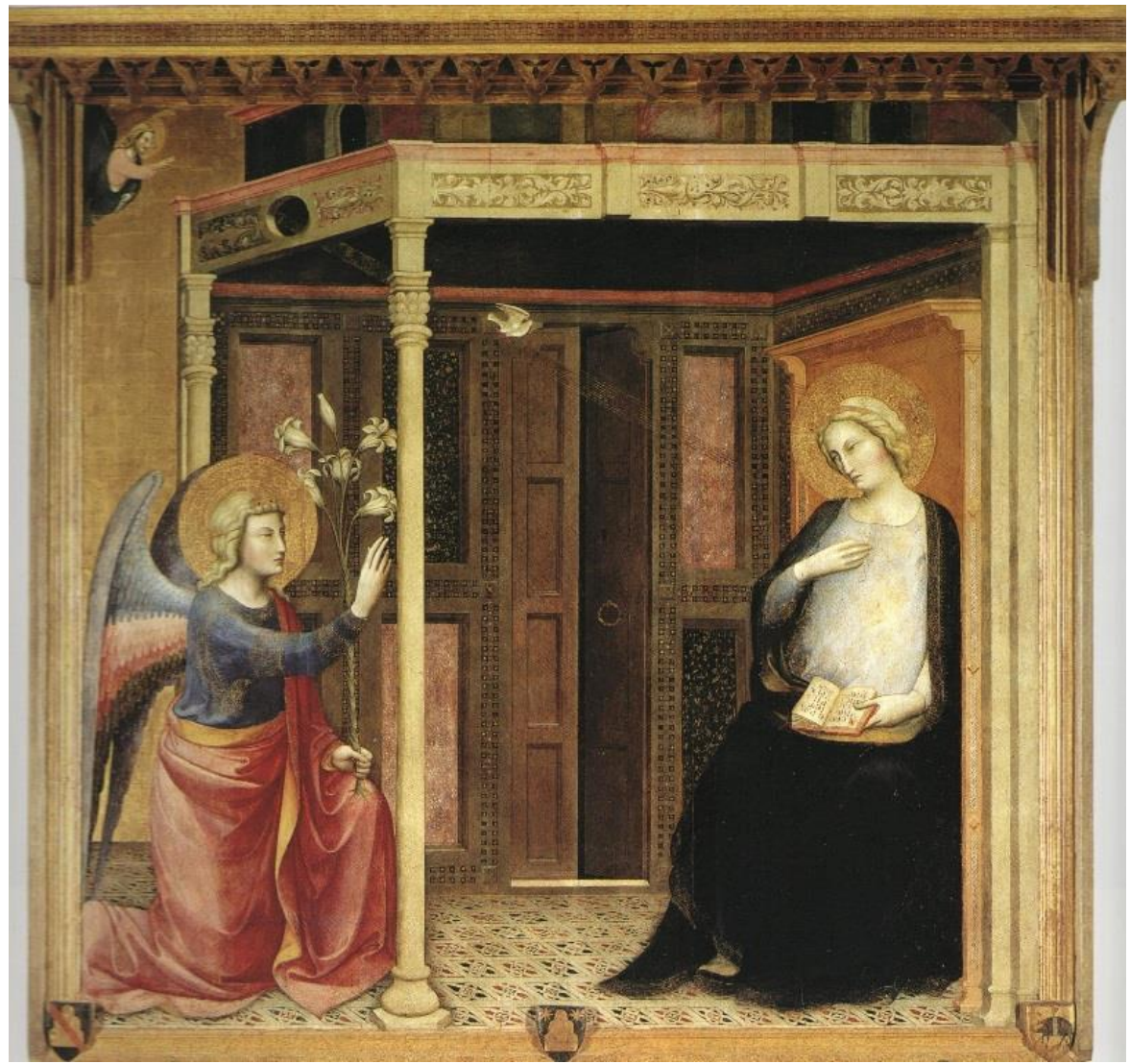

Fig. 1. Master of the Madonna Strauss, The Annunciation, 1390-1395. Galleria dell'Accademia, Florence. Photo Wikimedia Commons

The Master of the Madonna Strauss (active c. 1385-1415) composes his Annunciation, c. 1390-1395, of the Galleria dell'Accademia in Florence (Fig. 1) with excellent narrative efficacy, despite the simplified geometry with which he designed the house of Mary. In the outer space, the angel, carrying in his left hand the symbolic stem of lilies, ${ }^{32}$ blesses the Virgin

\footnotetext{
${ }^{32}$ We have already elucidated the doctrinal connotations of the stem of lilies in the artistic representation of the Annunciation in the papers: José María Salvador-González, "Flos de radice lesse. A hermeneutic approach to the theme of the lily in Spanish Gothic painting of The Annunciation from patristic and theological sources", Eikón Imago, 4 (2013 / 2): 183-222; "Flos campi et lilium convallium. Third interpretation of the lily in the iconography of The Annunciation in Italian Trecento art from patristic and theological sources", Eikón Imago, 5 (2014 / 1): 75 96; "In virga Aaron Maria ostendebatur. A new interpretation of the stem of lilies in the Spanish Gothic Annunciation from patristic and theological sources", Eikón Imago, 3 (2013 / 1): 1-48; and "Sanctitate vernans virga Aaronis. Interpretation of the stem of lilies in the medieval iconography of The Annunciation according to theological sources", Art Studies and Architectural Journal, vol. 10, n. 9 (2015): 2-32.
} 
kneeling before her with respect. Mary is sitting in the loggia that acts as a living room, at the end of which the door to her bedroom is ajar. Surprised by the unexpected arrival of the heavenly messenger, she has interrupted her prayer in the book she is holding open on her lap, in whose open pages one can read the beginning of Isaiah's prophecy ECCE VIRGO CONCIPIET ET PARIET FILIUM $($ Is 7, 14). Because of the fear that the unknown visitor instills in her, she shyly throws her body back, while putting her right hand on her chest demurely and doubtfully, as if wondering how she could be a mother while remaining a virgin.

For our purposes in this article, it is interesting to highlight here the beam of light that God the Father --represented as a tiny half-length figure in the upper left corner of the painting-- sends towards the Virgin, taking with it the dove of the Holy Spirit. Following the interpretations of the Greek Fathers exposed above, this fertile ray of light from God the Father symbolizes once again God the Son, lux mundi, "Sun of justice", and "light illuminating those who sat in darkness".

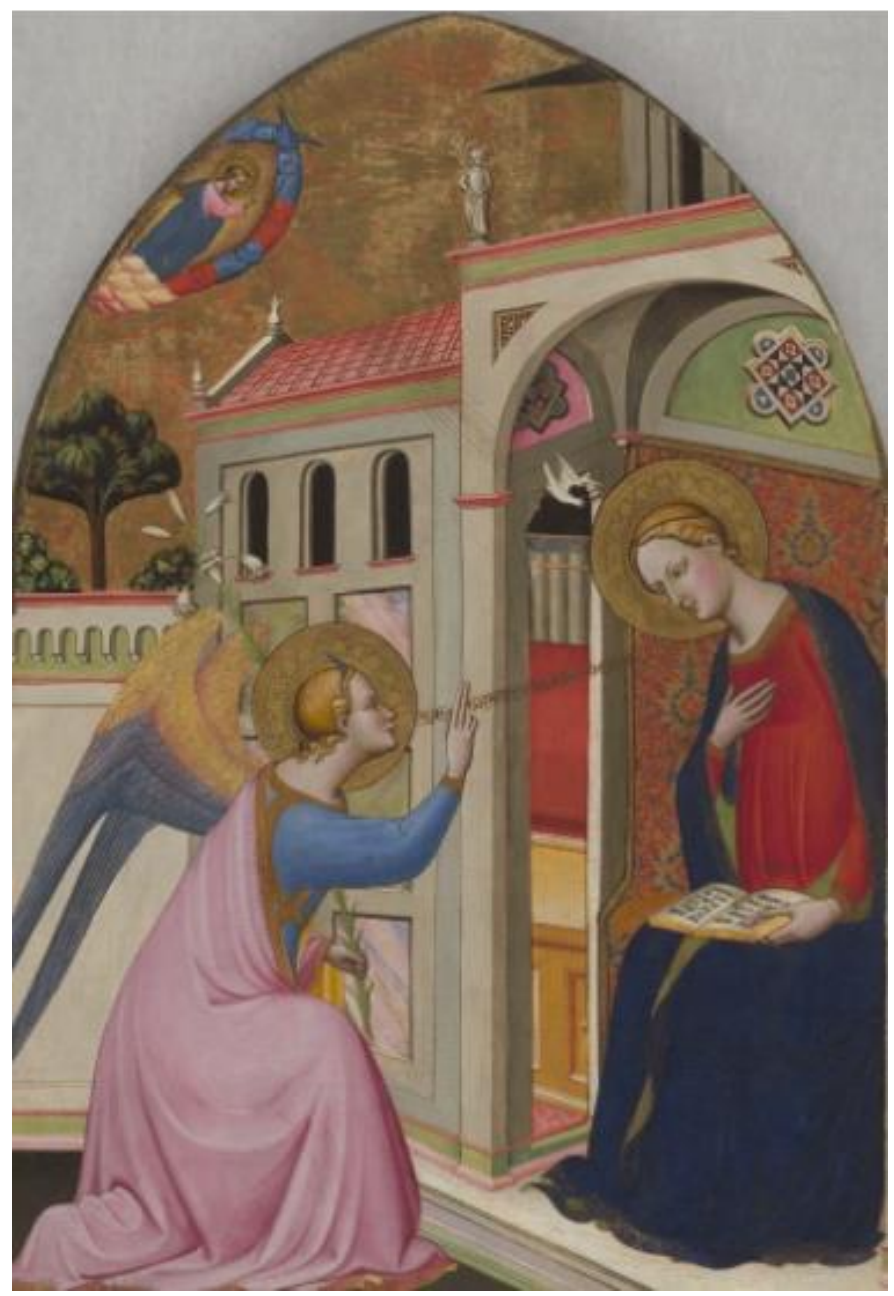

Fig. 2. Tommaso del Mazza, The Annunciation, c. 1390-1395. The Paul Getty Museum, Los Angeles. Photo Paul Getty Museum, LA 
Tommaso dal Mazza (active 1377-1392) organizes The Annunciation, c. 1390-1395, of The Paul Getty Museum in Los Angeles (Fig. 2), according to a lovely composition, in the context of a large building with a specific appearance of church and palace. In the outer courtyard, the angel, holding a stem of lilies in her left hand, blesses Mary, while expressing her respect with the usual flattering greeting, Sitting in a niche-shaped enclosure or small chapel, Mary interrupts her meditation in the book that she keeps on her knees to receive in a shy and crestfallen attitude the announcement that Gabriel communicates on behalf of the Most High. Levitating in the upper-left edge of the painting in the middle of a mandorla of cherubs, God the Father emits towards the Virgin the fertilizing beam of light with the flying Holy Spirit, to symbolize the conception/incarnation of God the Son, the "Sun of Justice ", the lumen gentium, the lux mundi, as numerous Greek Fathers deciphered all along many centuries.

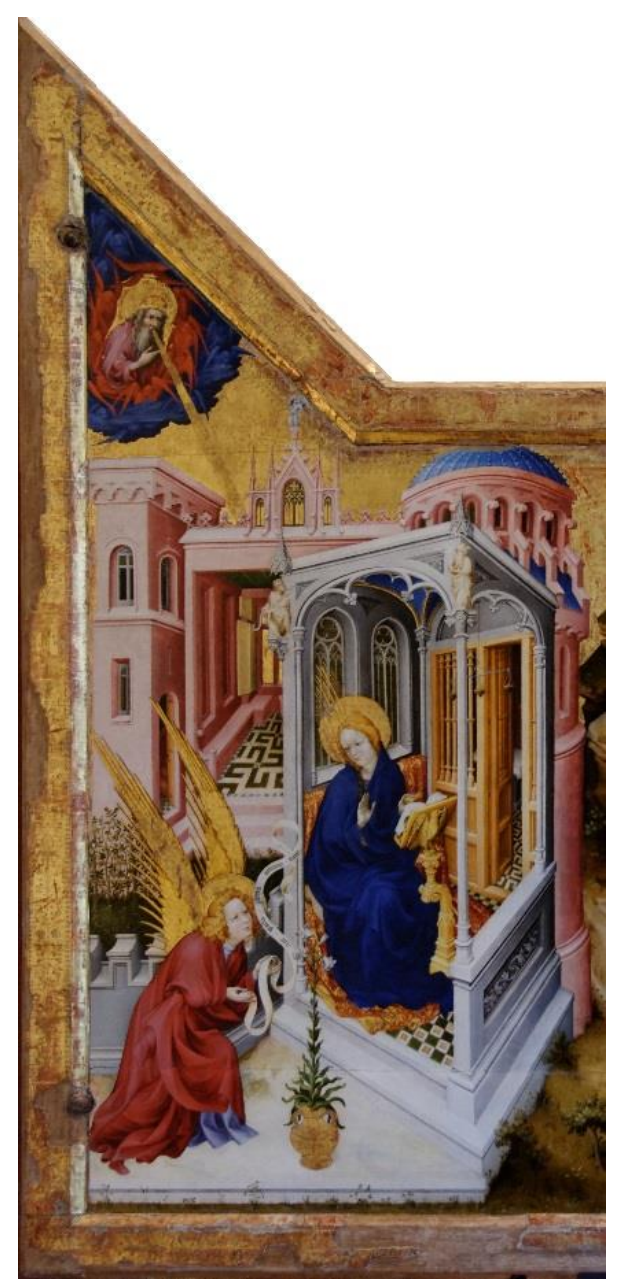

Fig. 3. MelchiorBroederlam, The Annunciation, the left wing of The Dijon Altarpiece, c. 1393-1399. Musée des Beaux-Arts, Dijon. Phto Wikipedia 
Melchior Broederlam (c. 1350-1410) designs the Annunciation of the Dijon Altarpiece (Fig. 3) in the context of a grandiose and elaborate building that, although in many of its spaces looks like a palace, as a whole is more like a temple. ${ }^{33}$ Many historians and iconographers have commented extensively on the morphology of this unusual building, with a whimsical perspective. Some even, like Erwin Panofsky, ${ }^{34}$ provide some suggestive interpretations of the contrast between its Romanesque and Gothic architectural elements, combined in a single set.

In that surprising setting, Gabriel, kneeling reverently in the surrounding courtyard, greets the Virgin Mary with the praise Ave gratia plena Dominus tecum (Lc 1,28), who appears written in the phylactery unfolded in front of him. Seating before an open prayer book placed on a beautiful lectern, Mary turns her face towards Gabriel to listen to his message, while raising and extending her right hand to manifest her obedience to the surprising divine plan brought by the angel.

In this Dijon Annunciation, the beam of rays of light insufflated by God the Father who levitates among seraphim and cherubs in the left corner of the panel- towards the head of Mary is especially relevant. He illustrates once more, as a visual metaphor, the textual metaphors about Sol justitiae, lumen Dei, lampas, lux mundi, and other similar biblical expressions interpreted by many Greek-Eastern Fathers and theologians as symbols of Son of God incarnate.

\footnotetext{
${ }^{33}$ We have studied the doctrinal meanings of that temple in the Annunciations of these two centuries in the following articles: José María Salvador-González, "Iconographic interpretation of the temple as a theological symbol in images of The Annunciation of the 14th and 15th centuries", Fenestella. Inside Medieval Art, 1 (2020), 23-41; "Greek Fathers's interpretations on templum Dei as a double theological metaphor (3th-9th centuries)", Volynskyi Blahovisnyk, 8 (2020), 127-145; and "Latin theological interpretations on templum Dei until the Second Council of Constantinople (553): a double Christological and Mariological symbol" (article under evaluation in an academic journal).

${ }^{34}$ Erwin Panofsky analiza este Dijon Altarpiece en su célebre libro Early Nedtherlandish Painting, Its origins and character (1966 [1953], p. 86-89, 117, 131-134, 136, 166, 231, 288, 307, figs, 104, 105, 164).
} 


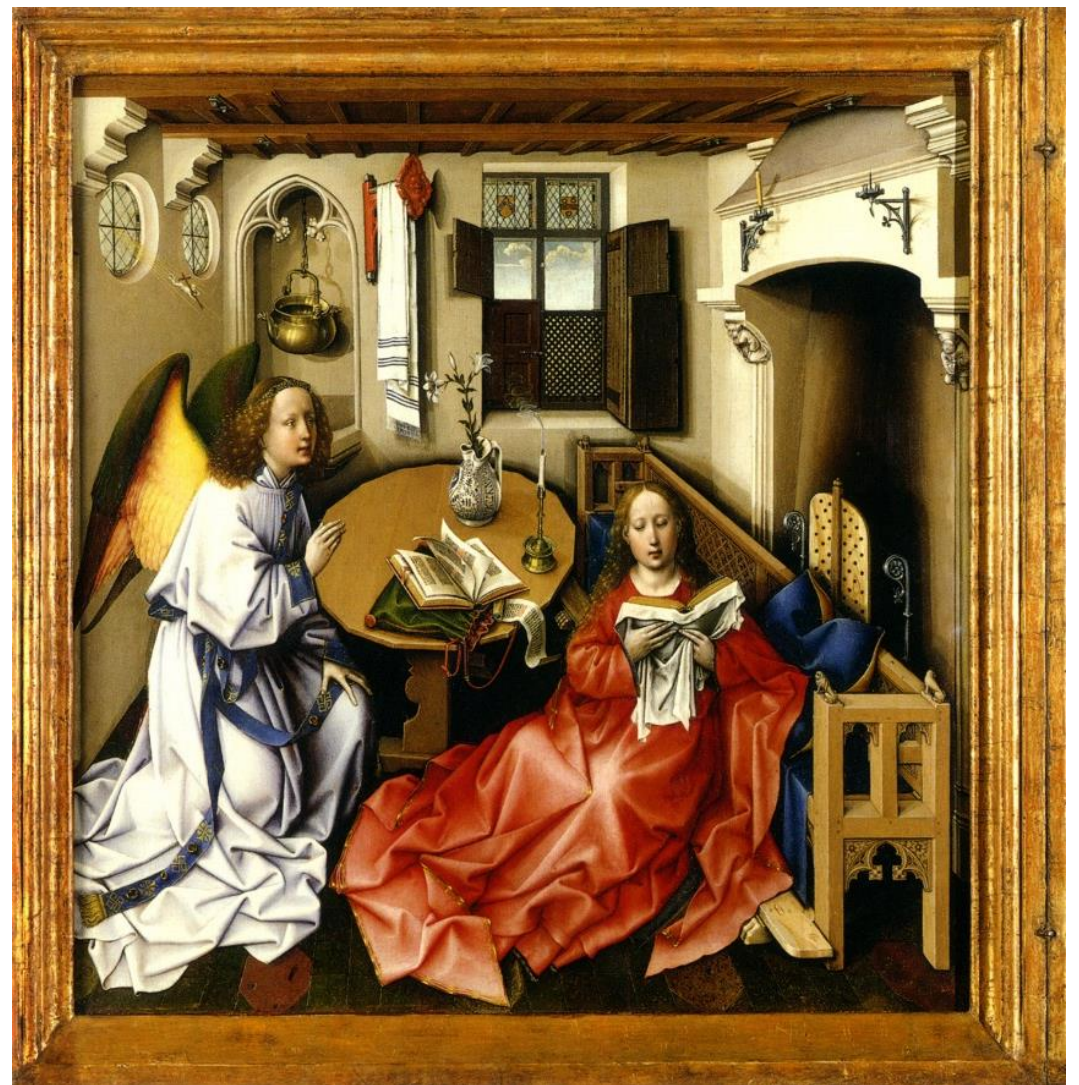

Fig. 4. Workshop of Robert Campin, The Annunciation, the central panel of The Mérode Altarpiece, c.1427-32. The Metropolitan Museum, New York. Photo The Metropolitan Museum

Con una visión minuciosamente realista, habitual en los pintores primitivos flamencos, Robert Campin (c. 1376-1444) - quien, según los expertos, contó en este tríptico con la ayuda de su taller - escenifica The Annunciation, central panel of The Mérode Altarpiece, c.1427-32, del Metropolitan Museum de New York (Fig. 4), dentro de una lujosa residencia burguesa flamenca, repleta de finos muebles y preciosos objetos domésticos. Pese a su aparente banalidad, muchos de esos objetos de uso diario (caldero con agua, toalla, florero con lirios, candelabros, libros, etc.) esconden ciertas significaciones simbólicas, que no mencionaremos aquí, por haber sido explicadas con mayor o menor pertinencia ya por algunos autores.

Robert Campin (c. 1376-1444) - who, according to experts, counted on this triptych with the help of his workshop - staged The Annunciation, central panel of The Mérode Altarpiece, c. 1427-32, of the Metropolitan Museum in New York, inside a luxurious Flemish bourgeois residence, full of fine furniture and precious domestic objects. Despite their apparent banality, many of those objects of daily use (cauldron with water, towel, vase with 
lilies, chandeliers, books, etc.) hide certain symbolic meanings, which we will not mention here, as they have been explained with more or less relevance already by some authors.

It is surprising that, after having omitted the representation of God the Father and even that of the Holy Spirit, the artist instead introduces here the figure of Christ, in the form of a tiny naked child / fetus, carrying a cross on his shoulder, flying towards Mary in the fertile beam of light emitted by the Most High. As it is logical to suppose, by adding this tiny Christfetus to the usual ray of light, the intellectual author of this Merode Annunciation increases powerfully and makes even more visible the Christological meaning of this ray as a symbol of God the Son Incarnate, as a metaphor of that lux mundi, lux quae illuminat omnes sedentes in tenebras, or this Sol iustitiae, in accordance with the interpretations of the Greek Fathers analyzed here.

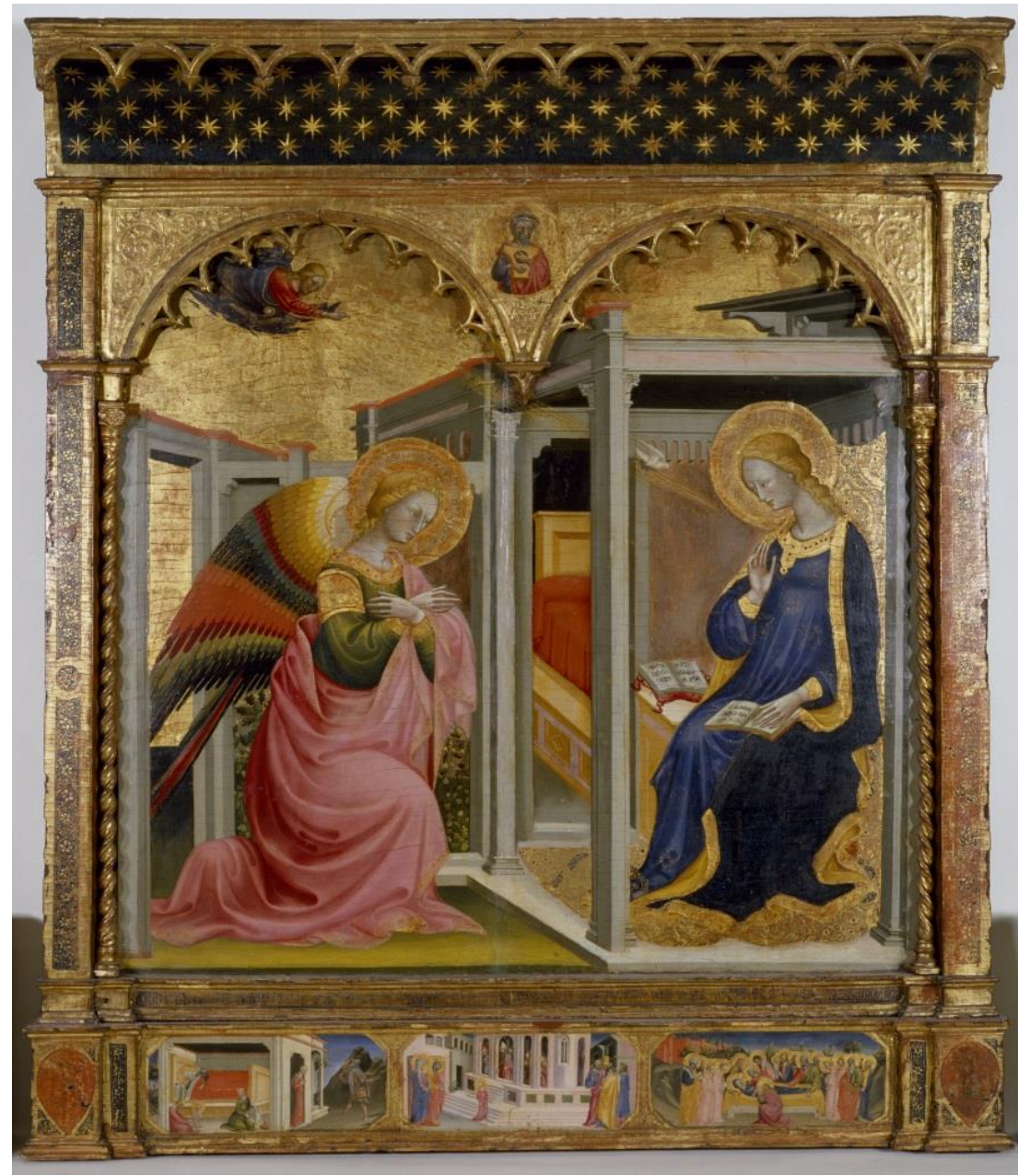

Fig. 5. Bicci di Lorenzo, The Annunciation, c. 1430. The Walters Art Museum, Baltimore. Photo The Walters Art Museum. 
Bicci di Lorenzo (1373-1452) organizes The Annunciation, c. 1430, of the Walters Art Museum in Baltimore in Maryland (Fig. 5) in a synthetic building structure of capricious volumetry, with discordant perspectives. The artist places the angel on his knees in a kind of patio or antechamber, crossing his arms over his chest and bowing his head to show his respect before the designated Mother of God. Seated in the room where she was being held in prayer, Mary interrupts the reading of the prayer book that she keeps open on her lap, before the unexpected arrival of Gabriel. At the end of the room, you can see through the open door the bedroom and the tidy bed of the Virgin. What is most important to highlight for our purposes in this article is the fertile beam of light rays that God the Father emits from above --with the Holy Spirit in his wake-- towards the Virgin. Experiencing the impact of the luminous ray, she submissively bows her head and raises her right hand outstretched to accept the divine project that the angel announces to her. By the interpretations given by the Greek Fathers on the biblical metaphors alluding to Sun, light, and flame, this ray of light appears thus as a symbol of God the Son made man to bring light to the world and dispel the darkness of error and sin.

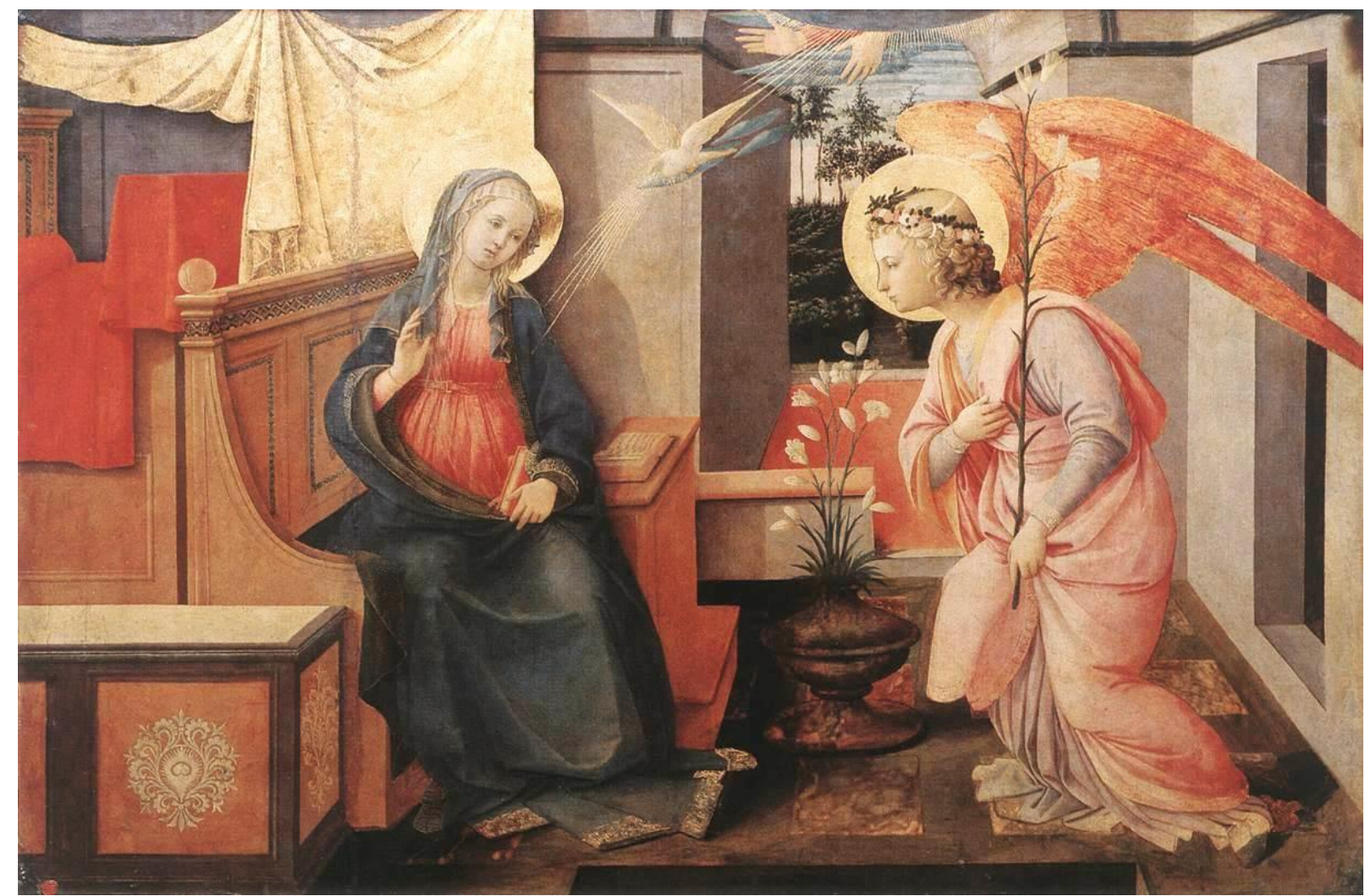

Fig. 6. Fra Filippo Lippi, The Annunciation, 1445-1450. Galleria Doria-Pamphilj, Roma. Photo Wikimedia Commons. 
Fra Filippo Lippi (c.1457-1504) introduces in his Annunciation, 1445-1450, of the Galleria Doria-Pamphilj in Rome (Fig. 6) some variants regarding the conventional structure of this Marian configuration. Thus reversing the usual position of the two features, the painter situates Gabriel on the right side and Mary on the left. Exceptionally he also duplicates the stem of lilies, putting one in the hand of the angel and another one in a vase on the floor. Seating aside her red bed, ${ }^{35}$ which an open yellow canopy covers, Mary turns her face towards Gabriel to listen to his announcement. The angel begins to kneel respectfully before his heavenly Lady while communicating her the divine message.

It is interesting to highlight here the powerful beam of light emitted towards the Virgin by the hands of God the Father, with a voluminous dove of the Holy Spirit in its wake, which leads several strange gray "little clouds" in the form of sharp ends. Who knows if the cult painter friar Fra Filippo Lippi, fully aware of the well-known Christological meaning of the beam of light as a symbol of the One who said that Ego sum lux mundi did not want to illustrate with those strange little sharp clouds that come from the Father to the Virgin in the ray of light together with the Holy Spirit the interpretations of the Greek Fathers when they identified the Virgin Mary as the cloud that revealed "the light of the world" or "the Sun of justice".

\footnotetext{
${ }^{35}$ We have studied the doctrinal meanings of the bed in images of the Annunciation in the following papers: José María Salvador-González, "The symbol of bed (thalamus) in images of The Annunciation of the 14th-15th centuries in the light of Latin Patristics", International Journal of History and Cultural Studies, Vol. 5, n. 4 (2019): 49-70; and "The bed in images of the Annunciation of the 14th and 15th centuries as a doctrinal symbol in the light of Greek Patristics", Imago. Revista de Emblemática y Cultura Visual, 12 (2020), 7-31.
} 


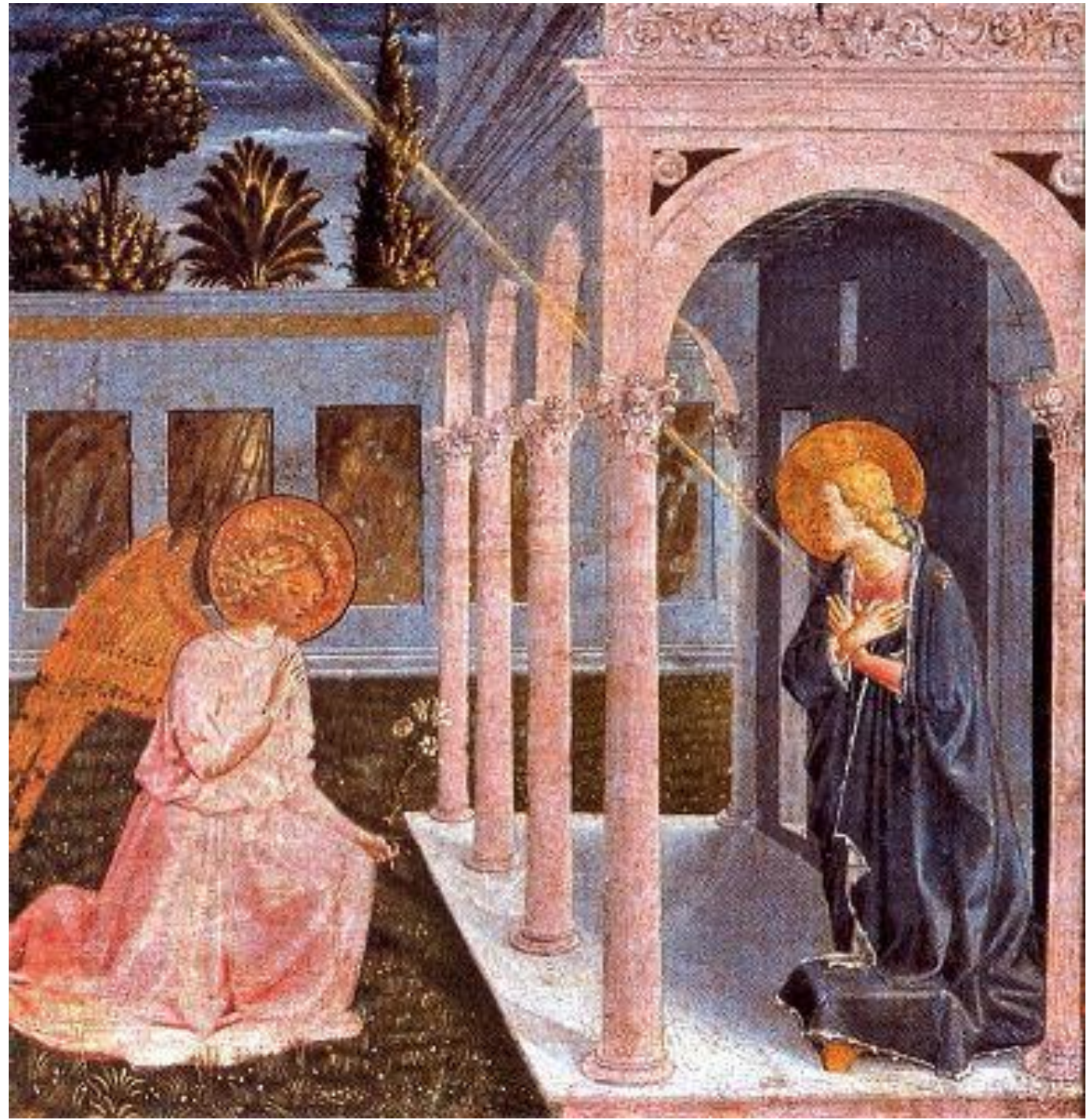

Fig. 7. Benozzo Gozzoli, The Annunciation, c. 1450-1452. Pinacoteca Vaticana. Photo Wikimedia Commons

Benozzo Gozzoli (1420-1497) sets The Annunciation, c. 1450-52, from the Vatican Pinacoteca (Fig. 7) within the framework of a sumptuous Renaissance palace of precious marble, whose garden is surrounded by a high wall, to symbolically signify the perpetual virginity of Mary as "closed garden" (hortus conclusus), according to the Husband's compliment to the Wife in the Song of Songs. Kneeling in the garden, Gabriel blesses the Virgin, holding in his left hand the symbolic stem of lilies. In the portico or loggia of the palace, Mary appears kneeling with her hands crossed on her chest, on which the long ray of light that emanates from the Most High impacts.

Several details surprise in this unusual interpretation of the Annunciation. In fact, regarding the traditional way of representing the Annunziata, Benozzo Gozzoli eliminates in this table the prayer book, the lectern, and the kneeler, the latter replaced here by a small platform, almost entirely covered by the Virgin's cloak. Furthermore, the painter omits the 
representation of the figure of God the Father and even the nearly inescapable dove of the Holy Spirit. Perhaps due to this double absence of the other two Persons of the divine Trinity, the artist emphasizes here the symbolic presence of God the Son, made visible by the long ray of light, a metaphor for Christ who is incarnated at that moment in the womb of the Virgin to, as the "Sun of justice" and "the light of the world", enlighten Humanity and dispel the darkness of their errors and sins, according to the explanations given by the Greek-Eastern Fathers above.

\section{Conclusions}

From what the two comparative analyzes of texts and images that we have made in this article, we can infer the following conclusions:

For more than half a millennium, from the 4th to the 9th century, many GreekEastern Church Fathers coincide in interpreting several biblical terms, such as Sol iustitiae, lux mundi, Oriens, lampas, and other similar metaphors alluding to luminous phenomena like others so many symbols of Christ, Son of God who is incarnated as a man to enlighten Humanity and dispel its darkness of error and sin.

As a necessarily correlative idea, many Fathers agree to metaphorically identify the Virgin Mary, in whose womb the Son of God the Redeemer is incarnated, as the "golden candelabrum" that supports the flame, as the "inextinguishable lamp", as the cloud that makes the Sun rise, or like the closed door through which the (Sun of) Orient passes.

From the reflection of the artistic images of the Annunciation in the 14th and 15th centuries, it follows that most of them include a beam of rays of light that, emitted by God the Father, and carrying in its wake the Holy Spirit in the form of a dove, falls upon the Virgin Mary.

The comparative analysis between both sets, texts, and images, studied here, confirms their essential mutual relationship: the texts of the Greek-Eastern Fathers and theologians textually explain and justify the ray of light in the images of the Annunciation; in turn, that ray of light painted in these images visually explains and illustrates the doctrinal contents revealed in the patristic texts.

Ultimately, this special beam of light rays painted works in the images of the Annunciation as a visual metaphor that illustrates the dogmatic contents explained by the 
Church Fathers when they interpret with Christological and Mariological projections the textual metaphors alluding to luminous phenomena mentioned above.

\section{REFERENCES}

\section{PRIMARY SOURCES}

Anonymus himnographus (c. 6th century). Hymnus 2. In: Alvarez Campos, Sergio (ed.). Corpus Marianum Patristicum. vol. V. Burgos: Aldecoa, 1981, p. 159.

Anonymus himnographus (c. 6th century). Hymnus 8. In: Alvarez CAmpos, Sergio (ed.). Corpus Marianum Patristicum. vol. V. Burgos: Aldecoa, 1981, p. 164-165.

Anonymus himnographus (c. 6th century). Hymnus 9. In: Alvarez Campos, Sergio (ed.). Corpus Marianum Patristicum, vol. V. Burgos: Aldecoa, 1981, p. 165-166.

Cyrillus AleXANDRINUS, Homilia XI. Encomium in sanctam Mariam Deparam. PG 77, 1.031-1.034.

Cyrillus AleXANDrinus, Adversus Nestorii blasphemias. Liber Primus, VII. PG 76, 47.

Ephremus Syrus. Carmina Sogita 4. In: Alvarez Campos, Sergio (ed.). Corpus Marianum Patristicum. Burgos: Aldecoa, 1970, vol. II, p. 499.

EusebIUS CAESARIENSIS. Eclogae propheticae. Liber II, 10. PG 22, 1.105.

Iacobus Sarugensis. Homilia de beata Virgine Matre Dei Maria. In: Alvarez Campos, Sergio (ed.). Corpus Marianum Patristicum. vol. V. Burgos: Aldecoa, 1981, p. 22.

IACobus SARUgensis, Homilia de sancta Dei Matre et perpetua Virgine. In: Alvarez CAmpos, Sergio (ed.). Corpus Marianum Patristicum. vol. V. Burgos: Aldecoa, 1981, p. 52-60.

IoAnnes Damascenus, Homilia in Nativitatem B.V. Mariae. PG 96, 661-679.

Josephus HyMnograPhus, Mariale. Theotocia seu Deiparae Strophae. PG 105, 1.041-1.279.

Josephus HyMnograPhus, Theotocia Ex Paracletica Graecorum. PG 105, 1.379.

JoSEPHUS HYMnOGRAPHUS, Mariale. Theotocia Sive Allocutiones ad beatam Virginem Deiparam. PG 105, 1.411.

Migne, Jacques-Paul, Patrologiae Cursus Completus, Series Graeca, Paris, Garnier Frères, 1857-1867, 166 vols.

Proclus Constantinopolitanus, Oratio II. De incarnatione Domini nostri Jesu Christi, et de infusoriis. PG 65, 691-704.

Proclus Constantinopolitanus, Oratio IV. In natalem diem Domini nostri lesu Christi, III. PG 65, 714.

Proclus Constantinopolitanus, Oratio VI. Laudatio sanctae Dei genitricis Mariae. PG 65, 754-722-758.

Romanus Cantor, Hymnus 16, 1. In Sergio Alvarez Campos (ed.), Corpus Marianum Patristicum, vol. 
IV/2, Burgos, Aldecoa, 1979, p. 132.

BIBLIOGRAFPHY

Alvarez Campos, Sergio (ed.) Corpus Marianum Patristicum. Burgos: Aldecoa, vol. II, 1970.

Alvarez Campos, Sergio (ed.) Corpus Marianum Patristicum. Burgos: Aldecoa, vol. IV/2, 1979.

Alvarez Campos, Sergio (ed.). Corpus Marianum Patristicum. Burgos: Aldecoa, vol. V, 1981.

BREHIER, Louis. L'art chrétien. Son développement iconographique dès origines à nos jours. París: Librairie Renouard-H. Laurens éditeur, 1928, 480 p.

Grabar, André. Les voies de la création en iconographie chrétienne: Antiquité et Moyen Âge. Paris: Flammarion, 1979, $341 \mathrm{p}$.

MALE, Émile. L'art religieux de la fin du Moyen Âge en France. Étude sur l'iconographie du Moyen Âge et sur ses sources d'inspiration. 7e éd., revue et corrigée. Paris: A. Colin, 1995, xi, 570 p.

PANOFSKY, Erwin. Early Nedtherlandish Painting, Its origins and character. Cambridge, Mass.; Harvard University Press, 1966 [1953].

REAU, Louis. Iconographie de l'art chrétien. Tome Second, Iconographie de la Biblie. II, Nouveau Testament. Paris: Presses Universitaires de France, 1957, 769 p.

SALVADOR-GonzÁlEZ, José María. Flos de radice lesse. A hermeneutic approach to the theme of the lily in the Spanish Gothic painting of The Annunciation from patristic and theological sources. Eikón Imago 4, n. 2, 2013, p. 183-222.

SALVADOR-GonzÁlez, José María. In virga Aaron Maria ostendebatur. Nueva interpretación del lirio en La Anunciación gótica española a la luz de fuentes patrísticas y teológicas. Anales de Historia del Arte 24, 2014, p. 37-60. Disponível em: https://doi.org/10.5209/rev_ANHA.2014.v24.47177.

SAlvador-González, José María. Flos campi et lilium convallium. Third interpretation of lily in the iconography of The Annunciation in Italian Trecento art from patristic and theological sources. Eikón Imago 5, n. 1, 2014, p. 75-96.

SALVADOR-GonzÁlez, José María. Per aurem intrat Christus in Mariam. Aproximación iconográfica a la conceptio per aurem en la pintura italiana del Trecento desde fuentes patrísticas y teológicas." Ilu. Revista de Ciencias de las Religiones, 20, 2015, p. 193-230. Disponível em: http://dx.doi.org/10.5209/rev_ILUR.2015.v20.50410.

SALVADOR-GonzÁleZ, José María. The Symbol of Bed (Thalamus) in Images of the Annunciation of the 14th-15th Centuries in the Light of Latin Patristics. International Journal of History and Cultural Studies, 5, n. 4, 2019, p. 49-70. Disponível em: http://dx.doi.org/10.20431/2454-7654.0504005.

SALVADOR-GonZÁLEZ, José María. Iconographic interpretation of the temple as a theological symbol in images of The Annunciation of the 14th and 15th centuries. Fenestella. Inside Medieval Art 1, 2020, p. 23-41. Disponível em: https://doi.org/10.13130/fenestella/12672.

Salvador-González, José María. Haec Porta Domini. Exegeses of some Greek Church Fathers on Ezekiel's porta clausa (5th-10th centuries). Cauriensia 15, 2020, p. 615-633. Disponível em: https://doi.org/10.17398/2340-4256.15.615-. 
SALVADOR-González, José María. "Greek Fathers" interpretations of templum Dei as a double theological metaphor (3rd-9th centuries). Volynskyi Blahovisnyk, 8, 2020, p. 127-145. DOI: https://doi.org/10.33209/2519-4348-2707-9627-2020-8-77.

SALVADOR-GonZÁleZ, José María. The bed in images of the Annunciation of the 14th and 15th centuries. A dogmatic symbol according to Greek-Eastern Patrology. Imago. Revista de Emblemática y Cultura Visual, 12, 2020, p. 7-31. Disponível em: http://dx.doi.org/10.7203/imago.12.17155.

SALVAdOR-González, José María. Latin theological interpretations on templum Dei until the Second Council of Constantinople (553): a double Christological and Mariological symbol (article under evaluation in an academic journal).

SCHILLER, Gertrud. Iconography of Christian Art. vol. I (Translated by Janet Seligman). London: Lund Humphries, 1971, $475 \mathrm{p}$.

SCHILLER, Gertrud. Ikonographie der christlichen Kunst. Band 4,1, Die Kirche. Gütersloh: Gütersloher VerlagHaus, 1988, $341 \mathrm{p}$.

SCHILLER, Gertrud. Ikonographie der christlichen Kunst. Band 4,2, Maria. Gütersloh: Gütersloher VerlagHaus, 1980, $472 \mathrm{p}$.

TosCANO, Giuseppe M. Il pensiero cristiano nell'arte. Bergamo: Istituto Italiano d'Arti Grafiche, 1960, 3 vols.

TRENS, Manuel. María. Iconografía de la Virgen en el arte español. Madrid: Plus Ultra, 1947, 715 p. 